\title{
DESIGN-RELATED PRODUCTS AND SERVICES MERCHANDISED THROUGH E-COMMERCE
}

\author{
Alfred Chen \\ College of Design \\ Kun Shan University of Technology \\ Rain Chen" \\ Department of Industrial Design \\ National Cheng Kung University \\ 1, Ta-Hsueh Road, Tainan City, Taiwan, 701, R.O.C.
}

\begin{abstract}
This study focuses on the application of design-related services in E-Commerce (EC). The authors propose a business model applicable to EC, attempting to merchandise design-related products and services (including patent, innovative design, as well as design and marketing consulting) over the Internet. The model includes front store, back office (Design Management Platform, DMP), knowledge base, and Strategic Alliances Network (SAN). It creates a new way to improve the conventional design-related services, integrate resources, and provide new business opportunities for future entrepreneurs.
\end{abstract}

Keywords: B2B, design, patent, business model, merchandise, EC

\section{INTRODUCTION}

"E-Commerce" is a concept represented by transforming conventional transaction into an electronic commerce. EC has many advantages such as the geographic limit for customers now vanishes, and there will be a drastic increase of customers. Administrative and advertisement expenses will be saved, as it is less expensive to put merchandises online than to put them in a conventional store. Advertisement will be more effective, for the reason that the Internet is globally accessible. The buyer and seller both save time, since all of the transactions will be done in a matter of minutes.

The statistical survey concerning U.S. Internet conducted by Mandel [6] has shown that EC is the main trend. Mandel proposed three important indexes in his research: 1) national online percentage, 2) investment in technology, and 3) sales growth trend, as depicted in Figure 1.

Mandel's research described the relationship between the investment in the Internet and the growth of the Internet in U.S. for the past several years. Hamm's study [4] further introduced another three indexes: 1) growth rate of EC, 2) organizations' Internet usage rate, and 3) percentage of E-BIZ projects in the leading role, as depicted in Figure 2. Undoubtedly, the studies done by Mandel and Hamm have proven the potential of business opportunities provided by EC.

\footnotetext{
* Corresponding author:maxrain@ms23.hinet.net
}

In addition, Figure 3 supports that $\mathrm{EC}$ is the trend by showing that $92 \%$ of the top 1,000 companies in U.S., according to a survey [7] by U.S. Fortune magazine, have adapted the EC mechanism. It clearly reflects the importance for U.S. companies to adapt to EC mechanism as soon as possible.

From the facts mentioned above, the authors have drawn a conclusion, which is that EC has become a major tool for companies to transform organizational structure, strengthen competitive-ness, and reduce cost. The advancement of the Internet financial transaction mechanism and secured data transmission mechanism has increased organizations' intention and willingness to participate in EC. Besides, the pressures from the competition and the EC's advancement have become the two forces to push the organizations to turn old commerce into EC. Furthermore, the application of EC is expected to be even more popular in the future.

However, not all EC models show a high growth rate. Based on the most recent report released by Dataquest [3], only Business-to-Business (B2B) has been growing satisfactorily. The B2B market value will leap from 120 billion U.S. dollars in 2000 to 2,700 billion U.S. dollars in 4 years, as shown in Figure 4. It indicates that EC is heading in a new direction of business integration.

EC will cause immense changes in organizations' internal and external operations, and these changes include: unlimited market scope, prompt information 


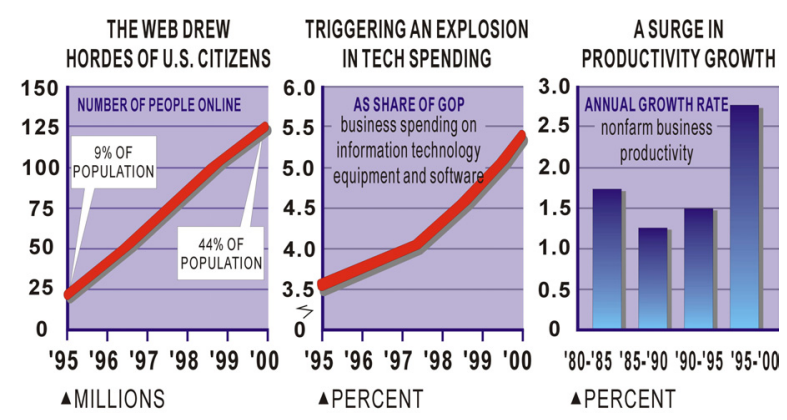

Data: Jupiter, Media Metrix Inc., Commerce Dept., Bureau of Labor Statistics Figure 1. The ups and downs of Internet

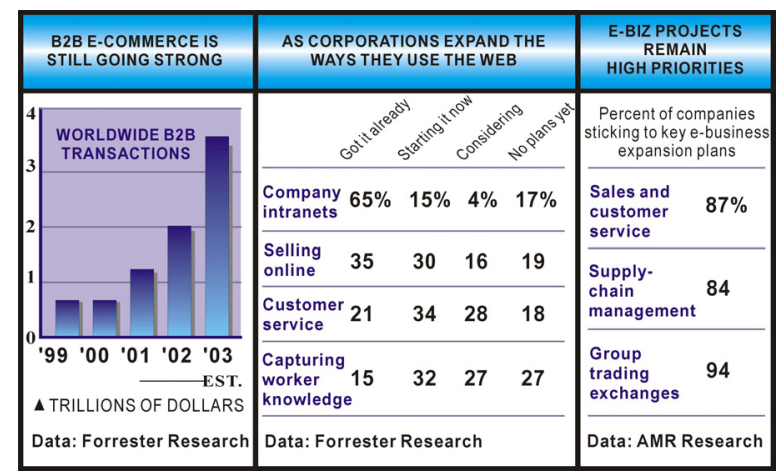

Figure 2. E-BIZ grow up

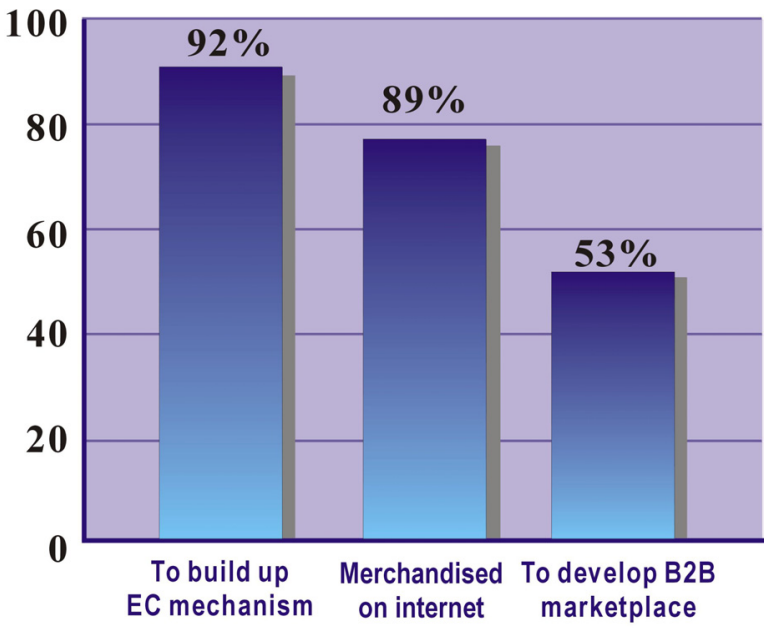

Data: PricewaterhouseCoopers Research

Figure 3. The percentage of U.S. top 1,000 big companies involved in EC

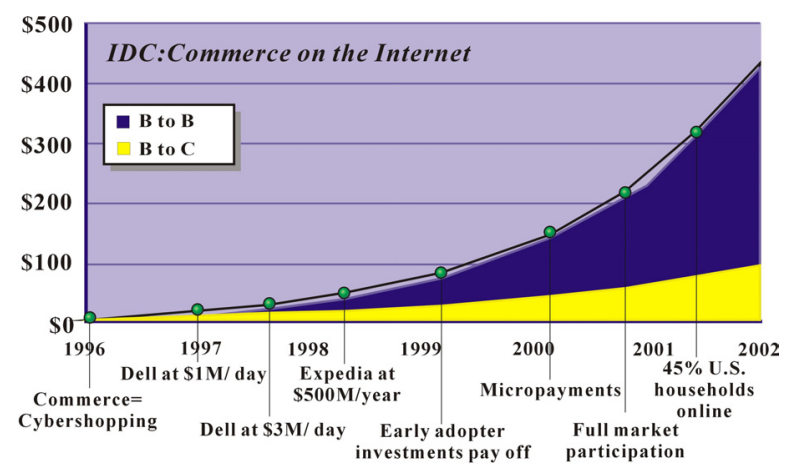

Data: Dataquest Research

Figure 4. The ups and downs of B2B and B2C management, and secured transaction mechanism. In addition, the change in merchandised behavior will make organizations to deal with unlimited customers as well as potential competitors. The ultimate consequence is that organizational strategic planning will become even more complicated, and it will be even harder to define the niche.

Therefore, organizations introduce EC operating model in order to save costs and generate profits. However, when other competitors also adapt to e-business and e-commercialize operations, the business model will be the most critical determinant of organizational competitiveness.

\section{CHALLENGES TO CONVENTIONAL MARKETING OF DESIGN-RELATED PRODUCTS AND SERVICES}

Organizations' survival and constant growth depend on continuous development of niche products and services. Meanwhile, due to many adverse factors in Taiwan such as the rising wages, strict environmental protection requirements, and obsolete government laws and regulations, organizations have to expedite the pace to shift business out of Taiwan. For a long time, companies have largely relied on OEM to make profit, but yet, not successful. For the companies who have not yet shifted out of Taiwan are at such a critical moment to re-define the value chain, or else they will go out of business. The probable trend is oriented toward design chain and marketing chain.

Based on years of observation and research in the field of successful organizational transformation experiences, the authors are able to conclude that, the better model is to transform from OEM to ODM then finally to OBM. [5]. When the organization transforms to ODM, the "design chain" must be emphasized, which requires the organization to strengthen its research and development capacity for design. When the organization transforms to OBM, the investment in "marketing chain" must be increased, and the organization must devote to exploration and expansion of marketing channels for OBM products.

There are two most commonly recognized kinds of design chain in organizations. One is to establish a specialized design department within the organization. Usually only large organizations are capable of doing it. The other one is to outsource design. Most companies in Taiwan currently implement either one or both of them simultaneously (ex: Acer's Aspire Project). The characteristics of the two kinds of design chain are described as follows:

1. The design department within the organization (In-house design) 


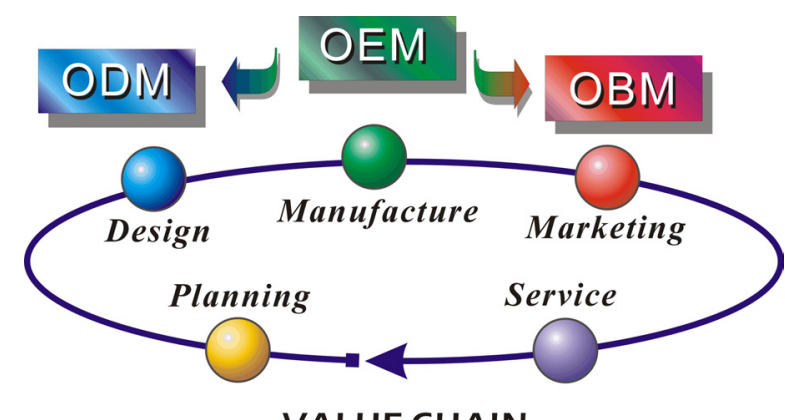

Figure 5. Shift of organizational value chain

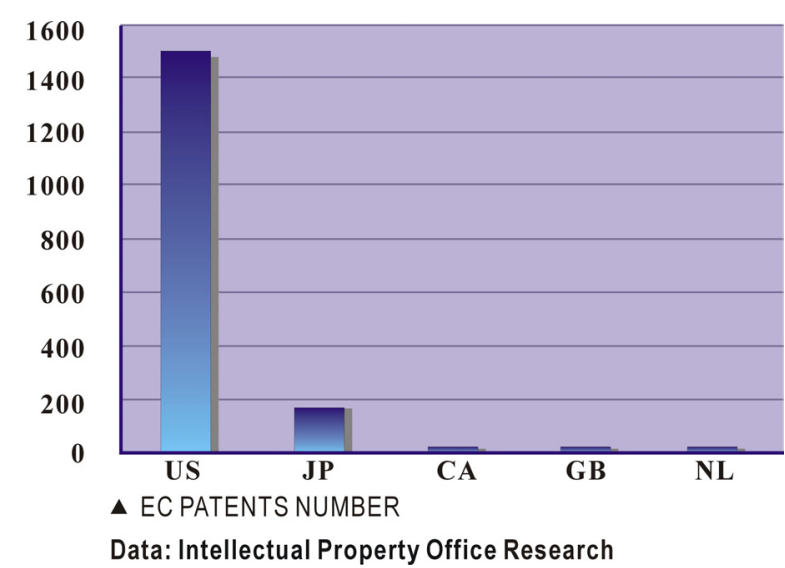

Figure 6. The number of patents on EC in different countries

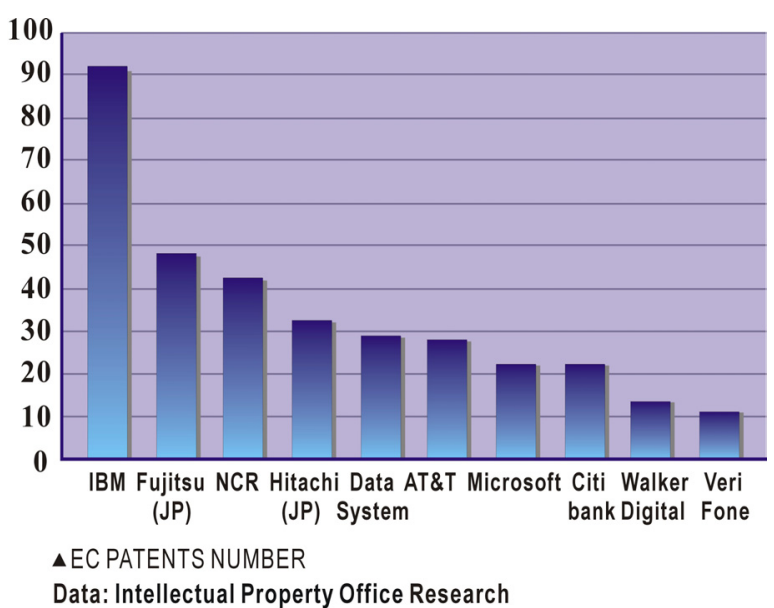

Figure 7. The top ten companies with patents on EC

Table 1. The difference between design and general commodities

\begin{tabular}{|l|l|l|}
\hline Comparison & Design & $\begin{array}{l}\text { General } \\
\text { commodities }\end{array}$ \\
\hline Pattern & not concrete & concrete \\
Property & intangible asset & tangible asset \\
Subject for Sales & ideas & products \\
Output & individual & mass \\
\hline
\end{tabular}

(1) The design output targets fitting the company's overall operational (or business) objective.

(2) The timing of the start and completion of a design is constrained by product ional processes.

(3) The design strategies are influenced by corporate culture and policy.

(4) It is very costly to build and maintain such an operation.

2. Outsource design

(1) Design consulting firms can usually provide specialized professional services.

(2) Design consulting firms can usually offer advices and ideas of originality and creativity.

(3) It is hard to predict the quality of the personnel cooperation and coordination between the client (the consulting firm) and the contractor (the organization).

(4) It is difficult for the contractor to manage the total quality of the outsourced services.

(5) Expenses occur case by case, without costs of building and maintaining operation incurred.

The two prevailing design chain mechanisms described above have some advantages as well as disadvantages to organizational operation. Organizations can actually implement both of them simultaneously according to individual needs. However, the emergence of EC has caused changes in conventional "design chain". The authors propose a new business model, differing from the conventional one, which takes advantage of the strengths of EC to build an EC platform committed to marketing "design" and supplying design-related products and services. This new business model will challenge the existences of the in-house design practices and the outsourcing design consulting firms' operations. What is predictable is that a reasonable, cost-effective, timely, and borderless design services model will become one of the most innovative alternatives for a vast number of entrepreneurs.

\section{NEW BUSINESS MODEL}

While EC is becoming the major commercial transaction trend, the merchandises of design-related products and services will not be excluded. However, it is not omnipotent to shift conventional commerce to online operation. Without a good EC business model, the only change occurred is from conventional commerce to opening online stores.

It is not easy to conceptualize and construct a good business model. Hence, the business model itself has become a strategy for companies to succeed in competition. In the "State Street Bank \& Trust Co., v. 


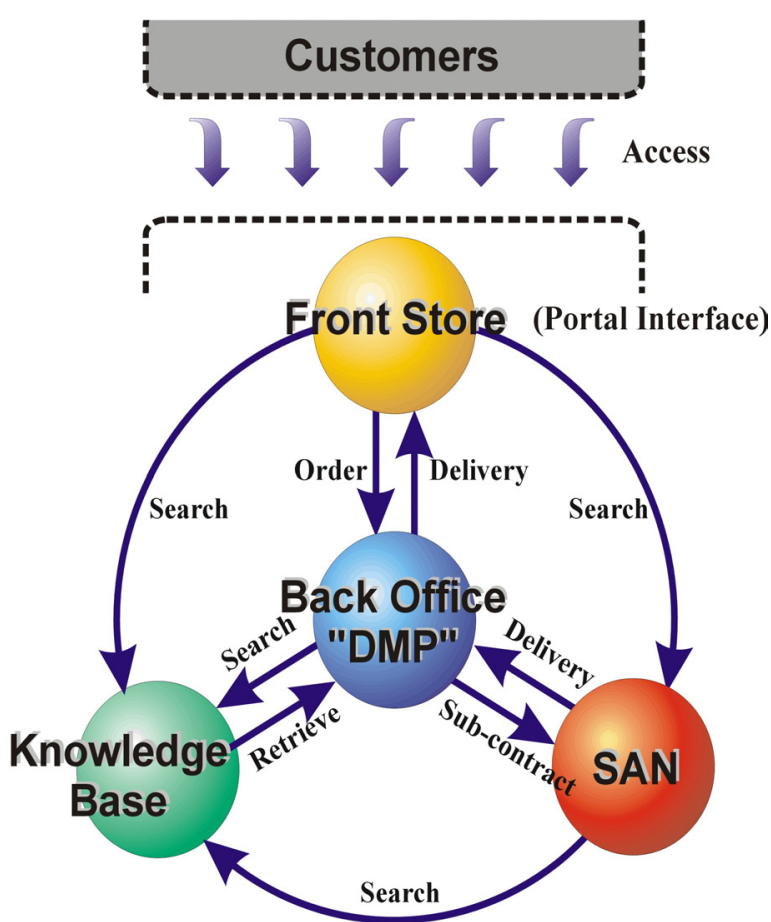

Figure 8. EC merchandise model for design

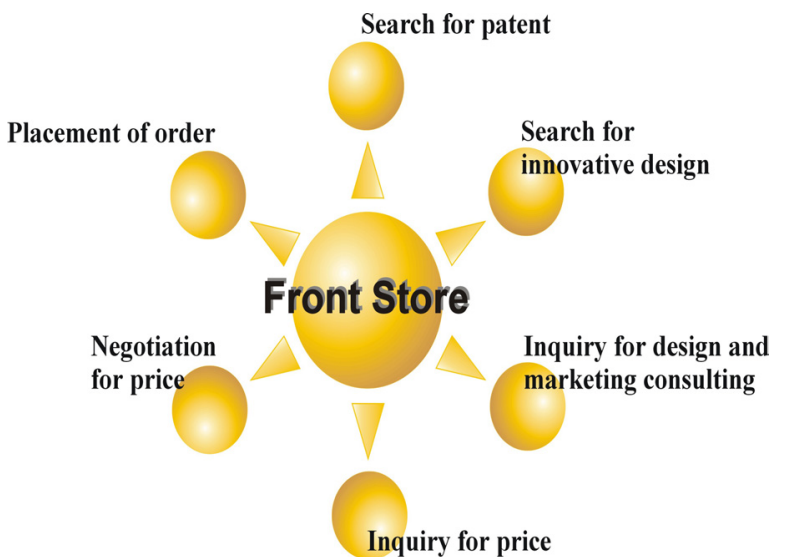

Figure 9. Front Store

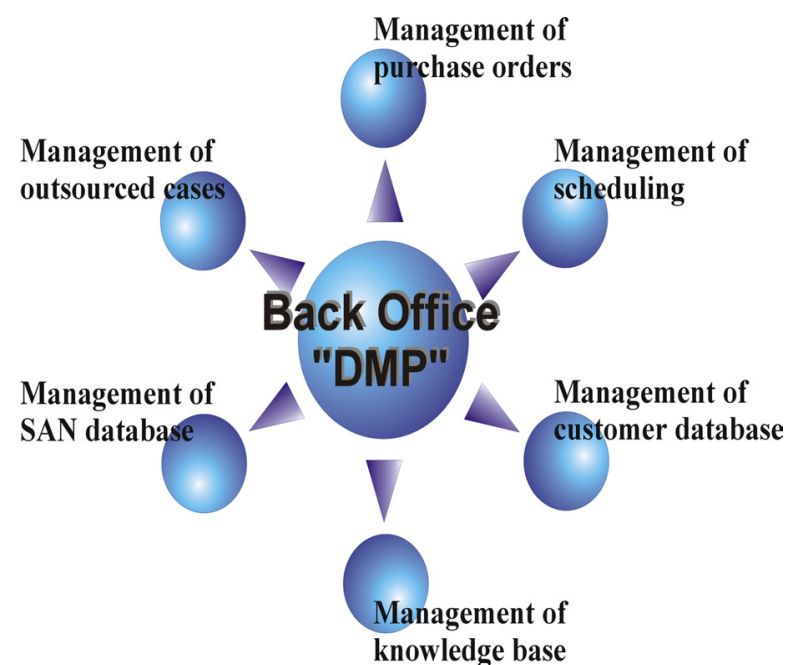

Figure 10. Back Office (Design Management Platform, DMP)
Signature Financial Group, Inc." case on July 23, 1998, U.S. Federal Circuit Court made the famous verdict by considering business model and method of doing business as the subjects of patent [8]. Since then, in advanced countries, EC business model has been protected as patent. Figure 6 lists the number of approved patents on EC in different countries. United States has a far larger number of patents on EC than other countries [2].

Moreover, Figure 7 shows the ranking of top 10 organizations with respect to the number of patents on EC they have. The top three are IBM, Fujitsu and NCR [2]. It is predictable that when these companies use the monopoly of patent as the weapon in competition, the potential business opportunities underlying EC are even more tremendous.

In advanced countries, the intellectual property institutions include "EC" in the subjects of patent protection, undoubtedly confirming the value that can be created by knowledge, which deserves appropriate proprietary protection. If design is merchandised through EC, patent protection of EC is a direct feasible method.

Since "design" differentiates from general commodities, the differences, as described in Table 1, must be taken into account.

The operating mechanism involved the merchandise of design-related products and services through EC, including highly developed technologies such as Internet financial transaction mechanism (SET, as an example), secured data transmission mechanism (SSL, as an example), and video communication mechanism (Net-meeting, as an example). This study attempts to develop an EC business model that can be implemented online, which consists of such four parts as front store, back office (Design Management Platform, DMP), knowledge base, and strategic alliances network (SAN), as shown in Figure 8.

The core of the model is back office (Design Management Platform, DMP), operated by a well-organized design management team (DMT). When customers place orders to DMP, DMT will retrieve appropriate products or services from knowledge base according to their needs. If unfortunately the retrieved stuffs do not meet their requirements, SAN will be on-call to provide a further assistance.

1. Front Store

The front store is a portal interface where different users have different authorized accessibility. This is the means of transaction of front store. It has functions as follows:

(1) Search for patent

(2) Search for innovative design

(3) Inquiry for design and marketing consulting

(4) Inquiry for price

(5) Negotiation for price

(6) Placement of order 
By using authorized access, the registered members can search for the files of innovative design, whereas the unregistered members can only search for patents. In addition, DMT also accepts customized orders of design and marketing consulting services. By judging the nature of the orders, DMT will decide whether to process independently or just sub-contract them to SAN.

2. Back Office (Design Management Platform, DMP)

Back office is a design management platform (DMP) run by a design management team (DMT). The team includes people with design, marketing, business planning, and decision-making background. The operations of back office include:

(1) Management of purchase orders

(2) Management of scheduling

(3) Management of customer database

(4) Management of knowledge base

(5) Management of SAN database

(6) Management of outsourced cases

3. Knowledge Base

The purpose of establishing a knowledge base is to provide customers with handy knowledge about design or accommodate customized orders. Direct sales of stored design-related knowledge to customers can effectively save them a great deal of lead- time to develop a new product. Customized purchase orders can satisfy customers' differing requirements. The knowledge base contains three components, as follows:

A. Patents

(1) Invention patents

(2) New utility model patents

(3) New design patents

B. Innovative design
(1) Conceptual design
(2) Finished design
(3) Others

C. Design \& marketing consulting

(1) Strategic product design

(2) Strategic product planning

(3) Strategic marketing

(4) Proposal for creating niche products

(5) Proposal for creating niche markets

(6) Consumers' preferences studies

(7) Others

4. SAN (Strategic Alliances Network)

When customers' needs cannot be met in the knowledge base, DMT will seek assistance from SAN. In order to solve various sophisticated design problems, SAN must have professionals in different fields:

(1) Industrial designers

(2) Product analysts

(3) Product planners

(4) Marketing specialists

(5) Engineers / technical specialists

(6) Lawyers

(7) Patent agents

(8) Others

\section{SUMMARY AND CONCLUSIONS}

The business model has developed a brand new merchandising environment; i.e. selling design-related products and services through E-Commerce. In practice, further detailed performance specifications for the model must be built as soon as the model is defined. There are two performance specifications, which have been considered the key factors of the validity of the model, i.e. 1. the constructs of the front store interface and the back office mechanism and 2. the coordination of DMP and SAN.

1. The constructs of the front store interface and the back office mechanism.

Detailed and specific services for front store interface and back office mechanism have to be defined as soon as DMP has been built. The services will include:

A. Services for the front store interface

(1) Members' registration: authorized access provided by trust.

(2) Design information: free or to pay.

(3) Show case: for design firms and individual designers only.

(4) Promotion: E-shop for hot designs.

(5) Patent searching: domestic and international categories.

(6) Innovative design searching: for members only.

(7) Consultancy for design/marketing: for customized orders only.

(8) Trade: Inquiry for price, negotiation for price, placement of order, and Internet financial transaction mechanism.

(9) Marketing information collection: Quick response to consumers' needs by introducing the application of data mining technology.

(10) Customer services: necessary and friendly services provided.

B. Services for the back office mechanism

(1) Management of users' trust.

(2) Management of purchase orders.

(3) Management of scheduling.

(4) Management of customer database.

(5) Management of knowledge database.

(6) Management of SAN database.

(7) Management of outsourced cases.

(8) Management of marketing information.

(9) Management of marketing mechanism.

(10) Management of system maintenance.

It is apparently that there is a strong relation between the front store interface and the back office mechanism. The relationship will be graphically shown in Figure 13. 


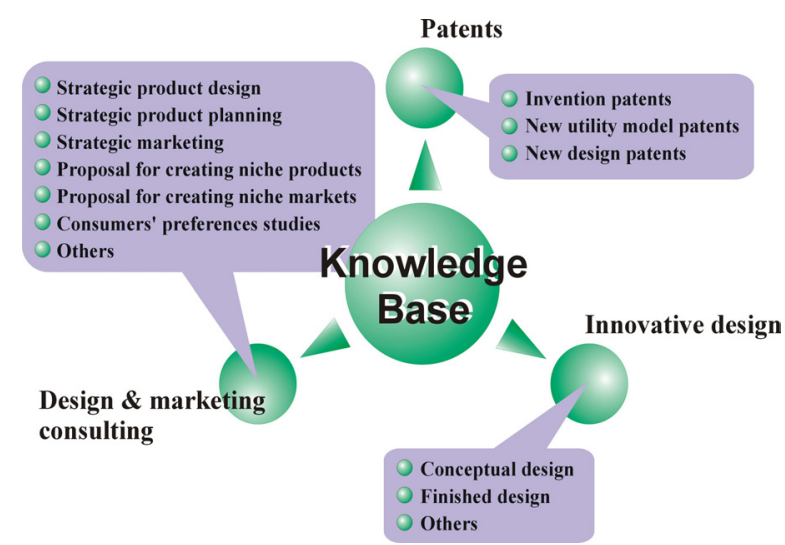

Figure 11. Knowledge Base

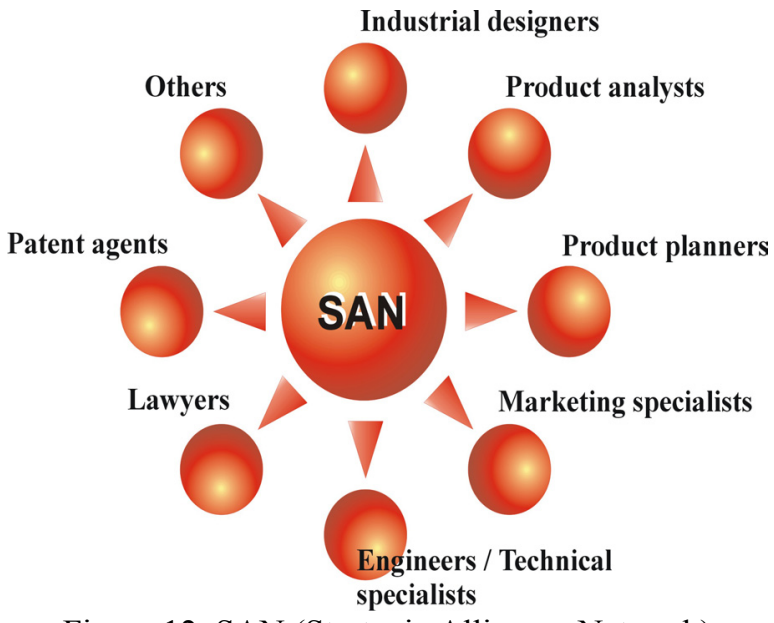

Figure 12. SAN (Strategic Alliances Network)
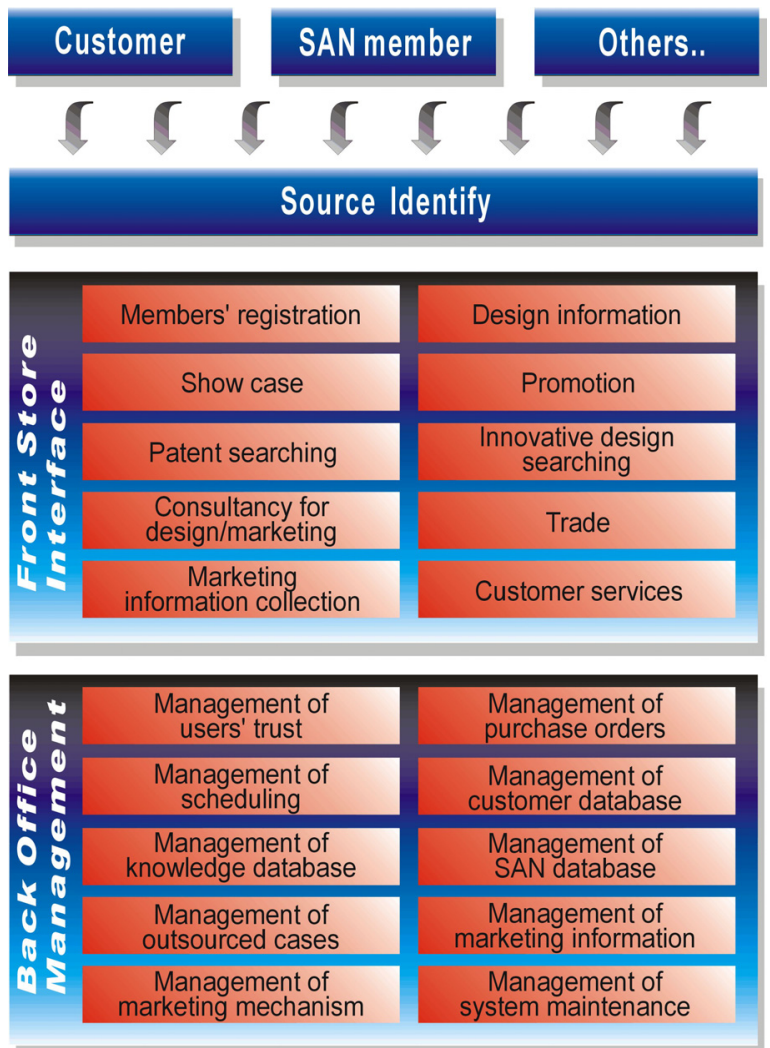

Figure 13. The constructs of the front store interface and the back office mechanism

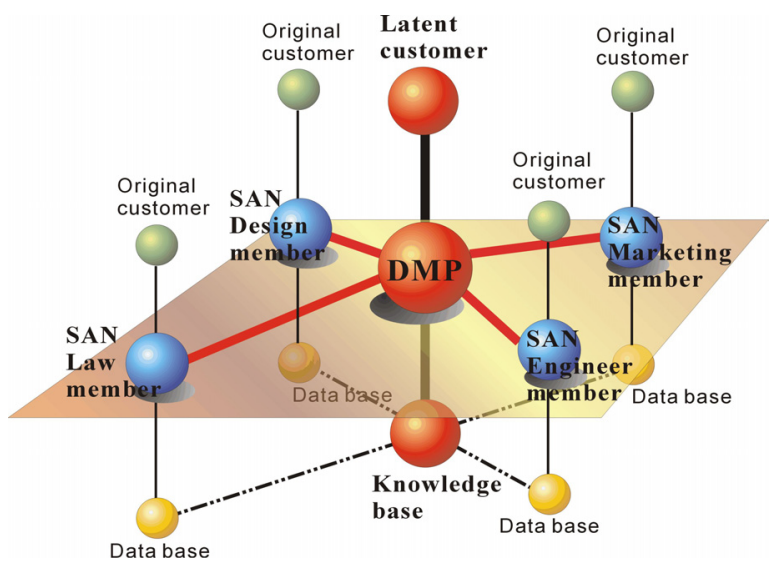

Figure 14. The coordination of DMP and SAN

\section{The coordination of DMP and SAN}

DMP, an operating system, is designed for a design management team. SAN, a manpower network, is composed of professionals from the chosen fields. DMP takes the most responsibility for sub-contracting the projects to a selected individual or team from SAN. In this case, DMP has provided the members from SAN extra business opportunities. The coordination of DMP and SAN will be graphically described in Figure 14.

The business model, integrating design management platform and strategic alliances network, completely skips the conventional design service mechanism, and provides a brand new business opportunity with EC as the operating system.

Borrus [1] proposed four future industries on the Internet that must be charged. They are Internet access, analysis, entertainment, and specialized services. This model fits the operating concept mentioned above.

The revolution brought forth by the EC merchandise model of design-related products and services is significant. It not only provides diversified commodities to the conventional market but also effectively develops the value of design.

\section{REFERENCES}

1. Borrus, A., "Someone has to pay the freight", Business Week, March 26, 56-57 (2001).

2. Chou, T., "The new global growth trend of EC patents", EC patent growth trend symposium, September 26, 1-11 (2000).

3. Dataquest, "IDC: Commerce on the Internet," online, Internet, Available, http://www.dataquest.com (2000).

4. Hamm, S., D. Welch, W. Zellner, F. Keenan and P. Engardio, "E-BIZ: down but hardly out," Business Week, March 26, 50-53 (2001).

5. Lee, C. J., C. H. Chen and H.C. Huang, "International division of labor and manufacturers' strategic choice/ODM strategy framework," The fifth industrial management symposium/The industrial innovation and globalization in Taiwan (1996).

6. Mandel, M. J. and R. D. Hof, "Rethinking the internet," Business Week, March 26, 43-48 (2001). 
7. Price waterhouse Coopers, "Total solution for new business," online, Internet, Available, http://www.pricewaterhousecoopers.com (2000).

8. Shao, Y. C., "EC patent strategies and inventors' new introspection", Intellectual Property Office, April 23, 1-2 (2000).

\section{ABOUT THE AUTHORS}

Alfred Chen was former Professor and Head of the Department of Industrial Design, National Cheng Kung University, Taiwan. He has been the Professor and Dean of the College of Design, Kun Shan University of Technology, Taiwan since August, 2001. His research interests include Computer-Supported Collaborative
Works, E-Commerce, CyberDesign Processes, and Knowledge Management Platform Design.

Rain Chen received the MS degree in Industrial Design from the National Cheng Kung University of Taiwan, Tainan City. He is an Instructor in the Department of Fashion Design, Shu-Te University, Taiwan. He is interested in Design Management, Design Patent and E-Commerce.

(Received October 2001; revised December 2001; accepted December 2001)

\title{
電子商務上設計產品與服務之銷售模式研究
}

\author{
陳連福 \\ 崑山科技大學設計學院 \\ 陳重任* \\ 成功大學工業設計系 \\ 701 台南市大學路1號
}

\begin{abstract}
摘要
本研究主要探討設計相關服務於電子商務上的應用, 並提出一種建立於電子商務 上的經營模式。該模式試圖將設計產品與服務（包含：專利、創新設計、設計與 行銷顧問等），於網路上直接進行交易，它包括：前台(Front Store)、後台(Back Office)即：設計管理平台(Design Management Platform, DMP)、知識庫(Knowledge Base)及策略聯盟網(Strategy Alliances Network, SAN)四個部份・此一新模式將改變 傳統設計服務觀念，進行資源整合，再造企業新契機。

關鍵詞：電子商務，設計，專利，企業模式，銷售 (聯絡人: maxrain@ms23.hinet.net)
\end{abstract}

